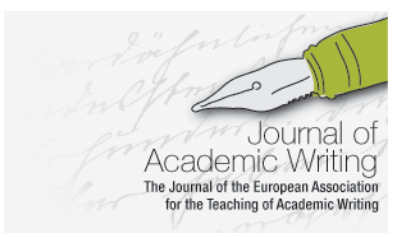

Journal of Academic Writing Vol. 8 No 2 Winter 2018, pages 229-232 http://dx.doi.org/10.18552/joaw.v8i2.445

\title{
Applying the 'Write Short' Concept in a University Degree Assessment Strategy
}

\author{
Justin O'Brien \\ Royal Holloway, United Kingdom
}

\begin{abstract}
It is a remark credited to several great writers: the admission, 'I didn't have time to write you a short letter, so I wrote you this long one instead'. Spilling your guts is easy; being concise takes time. Short is harder; content-rich, succinct writing requires supreme skill and considered application. This short paper argues the case that small is beautiful when we think about setting university assignment word counts.
\end{abstract}

\section{Mind the Skills Gap}

Three decades ago Rowntree said 'teachers tend to be trapped in a time-vortex that inhibits them' from developing integrated assessment regimes (1987: 3). The current UK situation is a far cry from Pressey's 1933 prediction that machine-powered education technology would free pupils and teachers from educational drudgery and modernise conventional education, which was, even back then, deemed grossly inefficient and clumsy (Rowntree 1987: 3). Too often, sadly, the essay prevails in traditional university assessment regimes, when a more diverse, blended diet of long and short, theoretical and vocational, would better prepare graduates for life after university. I want to argue, from a business school perspective, that small is beautiful when we think about setting university assignment word counts and invite readers to consider the applicability in their own discipline.

Stevens' (2005) research with Silicon Valley employers found that students needed stronger writing skills such as more professional email use, more eloquent self-expression and slang avoidance. Language skills are increasingly assimilated through omnipresent digital technology, cultivated in a world of peer-shared, user-generated content that emphasises ever more visual formats using fewer words, and young people experience more Netflix and peerto-peer YouTube than carefully curated BBC English (Loughrey 2018; Coughlan 2016). Is it not time, therefore, to use the web 2.0 revolution to re-genre the overly dominant essay assignment (English 2011)?

\section{Not Another 2,000 Word Essay}

The notion that all learning must be assessed using long-form essays can feel rather unavoidable (O'Brien 2017). The essay is decried by Adorno, Hullot-Kentor and Will (1984) who claim its tradition is unconvincing and its arduous requirements are infrequently achieved. Hines and Basso (2009) believe that many younger readers tend to be alienated by elitist writing, and encourage the use of an expressive, direct style that emphasises message meaning and intent rather than trying to impress with convoluted language. Too many traditionalists in UK Higher Education seem locked into the elastic essay syndrome, and rarely teach brevity and clarity explicitly. Progress from school to graduation is often evidenced by journeying from describing to being critically analytical, adding 500 words at each step up (Bloom et al. 1956). 
Advertising legend Bill Bernbach (1911-1982) revolutionised the advertising industry by recognising the power of short. He transformed advertising by cutting padded copy and harnessing the impact of crisp, white space with provocative images and succinct headlines. In a transparently connected world dominated by communication over mobile devices (Kotler, Kartajaya and Setiawan 2017), surely we need to bring forms of absolute minimalism into our students' armory, so they too can think and write small, powerfully.

The skill of being able to boil down a message to its pure essence, with not a single redundant word, is rather overlooked. Hines and Basso (2009) explain that effective writing for business presents the conclusion at the beginning, using concise and clear prose that enables meaning to be processed rapidly. Web content should also be succinct, not just in terms of the word count, but words, sentences and paragraphs should all be shorter according to Saleh (2014). Effective writing sees points made quickly and shrewdly, so that words and other people's time are not wasted.

In a more varied assessment diet I contend that less can actually be more. For example, when evaluating science, arts and social science graduates against each other, interviewers can identify successful candidates in the first three minutes of an interview (University of Kent, n.d.); the rest can just be legal box ticking. Is the same not true of assignments? Short assignments can be very dynamic and collaborative: for example, a management consultancy style report in PowerPoint with no more than 16 words per page, making a compelling speech as a radio podcast; a three-minute, individual, cloud-hosted video presentation; writing a single screen email; and drafting an executive summary.

I argue that too often university assessment regimes fail to evolve and retain relevance. I therefore urge you to think beyond elastic essays and be liberated to use a 'write short' assessment philosophy.

\section{How to turn a 2,000 word assignment into a short one?}

- Often, in a traditional UK context, systemic inertia first bites with the need to revalidate course documentation, so why not sidestep this hurdle and simply put more emphasis on the mark weighting of the abstract, introduction and summary and include the bibliography inside the permitted word count?

- The précis or summary has fallen rather out of fashion in the UK education system but time-poor business leaders value concise writing. A one- or two-page executive summary is a particularly challenging assignment that requires a clear mastery of the topic and the ability to address key priorities and/or recommendations.

- The prevalence of smartphone-based communication requires effective contemporary communicators to be able to get their message across using merely a heading, often just supported by very modest text and perhaps an image or two. Challenging students to write a single screen email, using the inverted pyramid approach favoured by journalists (Pöttker, 2003), can also help teach email etiquette and conventions.

- Why not embrace contemporary media technology and invite students to present a 500-word, 5-minute radio podcast or video talk uploaded to YouTube (or similar free hosting service), simultaneously building useful experience for job interviewing? Carefully crafted, well-researched scripts typically shine through. Facile it is not. 
- The most extreme format is a PowerPoint (or similar application) presentation slide deck, where text should be minimal and the storytelling narrative is achieved via a careful curation of the white space, graphics, data, powerful message-bearing headings and curt bullet points. Putting firm limits on slide numbers (10-15) and words per slide (16-50) fosters salience. This can work particularly well as a group assignment, as it requires students to work closely together and not divide their activity into individual tasks that are untidily stitched together just prior to submission.

\section{Reflection}

Savin-Baden (2003) maintains that inhibited faculty feel locked in, constrained by university and professional norms. Too often, traditional, production-led thinking stymies genuinely innovative practice. In my experience of breaking free from the usual practice, colleagues have been surprisingly open to alternative modes of assessment: indeed, the biggest challenge was my own pre-conception of what others would think of my 'radical' new ideas. I found in writing short, students were more precise in their use of language, demonstrated more topic focus and presented efficacious argument structures and articulation, important skills development which feeds forward into other assignments and also builds their employment prospects. Frankly, I wish I had embraced the 'write short' philosophy earlier. 


\section{References}

Adorno, T. W., Hullot-Kentor, B., and Will, F. (1984). 'The essay as form'. New German Critique (32), 151-171

Bloom, B., Englehart, M., Furst, F., Hill, W., and Krathwohl, D. (1956) Taxonomy of Educational Objectives, Handbook I: Cognitive Domain. New York: David MacKay Company

Coughlan, S, (2016) 'Time Spent Online "Overtakes TV" Among Youngsters'. BBC, 26 January. [online] available from <http://www.bbc.co.uk/news/education-35399658> [accessed 1 June 2017]

English, F. (2011) Student Writing and Genre: Reconfiguring Academic Knowledge. London: Bloomsbury

Hines, R., and Basso, J. (2009) 'Do Communication Students Have the "Write Stuff"?: Practitioners Evaluate Writing Skills of Entry-Level Workers'. Journal of Promotion Management 14 (3-4), 293-307

Kotler, P. Kartajaya, H., and Setiawan, I. (2017) Marketing 4.0: Moving from Traditional to Digital. Hoboken, NJ: Wiley

Loughrey, C. (2018) 'BBC admits more young people now watch Netflix far more than their content'. The Independent, 30 March. [online] available from $<$ https://www.independent.co.uk/arts-entertainment/tv/news/bbc-netflix-young-peoplewatch-more-iplayer-spotify-statistics-a8281706.html> [accessed 1 Jun 2017]

O'Brien, J. (2017) Small is Beautiful: The Importance of Writing Short. [online conference presentation] available from <https://youtu.be/a5mUmBLIcgM> [29 October 2018]

Pöttker, H. (2003) 'News and its communicative quality: The inverted pyramid—when and why did it appear?' Journalism Studies 4 (4), 501-511

Rowntree, D. (1987) Assessing students: How shall we know them? $2^{\text {nd }}$ edn. London: Kogan Page

Saleh, N. (2014) The Complete Guide to Article Writing: How to Write Successful Articles for Online and Print Markets. Blue Ash, OH: Writer's Digest Books

Savin-Baden, M. (2003) Facilitating Problem-Based Learning. Maidenhead: McGraw-Hill Education

Stevens, B. (2005) 'What communications skills do employers want? Silicon Valley recruiters respond'. Journal of Employment Counselling 42 (1), 2-9

University of Kent (n.d.) How to perform well at interviews. [online] available from <https://www.kent.ac.uk/careers/intervw.htm> [31 October 2017] 